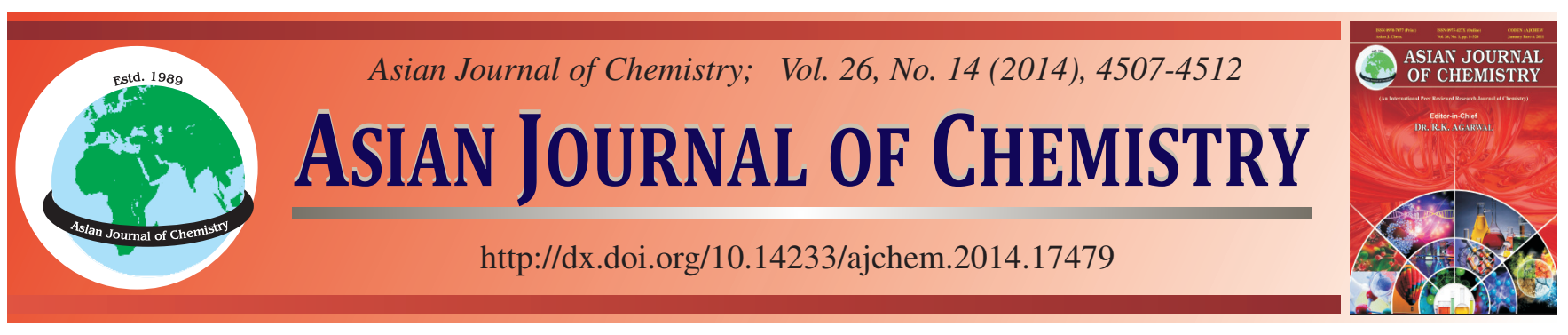

\title{
Effect of Aqueous Suspensions of Titanium Dioxide in Photoreactor with Radiation Source on Color Changes of Three Contemporary Composite Resins
}

\author{
Ameer H.H. Alameedee ${ }^{1,2, *}$, Hala A.M. Ragab ${ }^{1}$, Essam M.H. Osman ${ }^{1}$ and Falah H. Hussein ${ }^{3, *}$
}

${ }^{1}$ Faculty of Dentistry, Beirut Arab University, Beirut, Lebanon

${ }^{2}$ Faculty of Dentistry, Babylon University, Babylon, Iraq

${ }^{3}$ Chemistry Department, Faculty of Science, Babylon University, Babylon, Iraq

*Corresponding authors: E-mail: ameeralameedee@gmail.com; abohasan_hilla@yahoo.com

\begin{abstract}
The study performed to assess the effect of titanium dioxide using (Photoreactor) with the source of radiation on the color change of the three contemporary dental fillings by composite resin material. The resins were divided into three groups head of considering the type of charge and each group of which is composed of five discs and each disc thickness of $2 \mathrm{~mm}$ and diameter of $5 \mathrm{~mm}$ and manufactured by the mold of Teflon material and then been refined and soften the disc surface and stored in distilled water for one week at $37{ }^{\circ} \mathrm{C}$ in order to complete the polymerization. After the completion of the first week is staining the surface of disks and putting it in a solution of iodine mouth wash (AVALON pharma ${ }^{\circledR}$ ) at $37^{\circ} \mathrm{C}$ for a period of just one week after the completion of this week has been directed drive and put it in aqueous suspension consisting of titanium dioxide in Photoreactor Radiation with 355 NM periods of time 0, 5, 10, 15 and 30 seconds. Colorimetric readings were taken of the tablets based on, before staining substance iodine solution, after staining discs textured iodine solution and after treatment disks Palmalq water for titanium dioxide. In addition, the absorbance was measured after each period of time and put the disks. Palmalq watery results were analyzed statistically. There were significant effects on pay chromatography and the palace of color where are different for each group from the other and come the second group of the most influential change chromatography and minors chromatography and then finished second the third set. Finally, comes the first group, as well as influenced by absorbance time in extrusive and different for each group of the three groups of disk attributed to their chemical composition
\end{abstract}

Keywords: Photocatalytic decolorization, Restorative composite color changes, Titanium dioxide.

\section{INTRODUCTION}

The aesthetic goals of our patients and dentistry today have become increasingly demanding. The use of composite resins as tooth composite resins to achieve the optical properties of natural teeth. The aesthetic appearance of anterior teeth has become a major concern for patients. Discolored vital anterior teeth have long treated with different approaches, including crowns, direct, indirect veneers, composite resin and most conservatively bleaching. Both take-home and in-office bleaching techniques have proven effective in whitening teeth, with the latter having the advantage of producing immediate results ${ }^{1,2}$. In addition to color changes a compared by bleaching process, resin composite that exit on the tooth surface also may be cleaned may also change. These changes are effected by different factors, such as type concentration and exposer time of bleaching ${ }^{3-5}$.

Kim et $a l .{ }^{6}$ revealed that tooth whitening because negligible alterations on the color and the surface of a nano filled and two micro-hybrid resin composites. The composite resin composed of organic and inorganic phase has important effect in the degree of color and surface changes when exposed to the bleaching products ${ }^{7-12}$.

Resin materials are especially more prone to chemical alteration compared to inert metal or ceramic composite resin ${ }^{13-15}$. In addition, composite resins tend to discolor teeth due to their resin matrix hydrophilicity and water absorption properties, so the degree of discoloration may lead the patient and the dentist to replace composite resin composite resins over time ${ }^{16}$.

The typical in-office bleaching regimen involves application of a high percentage hydrogen peroxide formulation either to the teeth surfaces, which activated chemically or by a light source. The theoretical advantage of using lights is their ability to heat hydrogen peroxide, thereby enhancing the rate of oxygen decomposition.

The oxidation, in which the molecules causing discoloration are chemically modified ${ }^{17}$, and the increased amount of oxygen-free radicals produced thus enhances the release of stain-containing molecules and, therefore, results in enhanced whitening ${ }^{18,19}$. 
There are many reports concerning the effects of in-office bleaching on natural teeth, but its effect on tooth-colored composite resin is not, yet, fully known and resin composites are widely used as restorative materials because of their excellent aesthetic properties. However, their initial color may change over time because of surface and marginal staining, as well as internal material deterioration ${ }^{20,21}$. Staining of resin composites by beverages such as coffee, tea and soda or by mouth rinse agents has been reported to varying degrees ${ }^{22,23}$. In addition to color, surface characteristics contribute significantly to the aesthetic quality of composite resin. Surface roughness has a detrimental effect on light reflection, resulting in a dull appearance that stands out from the rest of the teeth.

Moreover, rough surfaces promote bacterial plaque adhesion, with subsequent increased staining ${ }^{24-26}$. also the tooth bleaching agents increased the tooth sensitivity and gingival irritation by the effect of its oxidizing, many studies have proved the decrease of the shear bond strength by use of any bleaching agent either in vitro or in vivo ${ }^{27}$.

Other studies find that high concentration hydrogen peroxide with calcium was less effective in deep dentin than $10 \%$ carbamide peroxide ${ }^{28}$.

Titanium dioxide photocatalyst $\left(\mathrm{VL}-\mathrm{TiO}_{2}\right)$ and $\mathrm{H}_{2} \mathrm{O}_{2}$ containing with visible-light activating were introduce in some new in-office bleaching agent were recently developed. Titanium dioxide was used in different cleaning applications is had a very low toxic level and inexpensive substance. Titanium dioxide also known as the most important semiconductor photocatalyst reacting to ultraviolet light ${ }^{29}$. VL- $\mathrm{TiO}_{2}$ was made from original titanium dioxide photocatalyst and the application of visible light on a bleaching agent containing $\mathrm{H}_{2} \mathrm{O}_{2}$ and VL-TiO could increase the bleaching efficacy ${ }^{30,31}$. The $\mathrm{VL}-\mathrm{TiO}_{2}$ were photocatalyst reacting material to visible light especially at low wavelength ${ }^{30}$. The purpose of this study was to determine color change of three nanofilled composites, when subjected to iodine staining and bleaching using chemically activated visible UV light bleaching material. The null hypothesis was that the three-nano filled composites would respond similarly to the aqueous suspensions of titanium dioxide in photoreactor.

\section{EXPERIMENTAL}

Three resin composites specimens i.e., Beautifil II [bisphenylglycidyl dimethacrylate (Bis-GMA) $7.5 \%$, triethylenglycol dimethacrylate (TEGDMA) $5 \%$, alumino-fluoro $70 \%, \mathrm{Al}_{2} \mathrm{O}_{3}$ (borosilicate glass). DL-camphor quinone, (Shofu Dental Corporation, USA)], IPS Empress Direct [paste of dimethacrylates, copolymer 20-21 wt. \%, barpum glass 77.5-79\% wt., ytterbium trifluoride (550 nm), Initiators, stabilizers and pigments, (Ivoclar Vivodent, USA)] and Ceram.x.mono [methacrylate modified polysiloxane, dimethacrylate resin, Ba-Al-borosilicate glass $70 \%$, pyrogenic $\mathrm{SiO} 257 \%$, camphorquinone, ethyl-4-diemethylamino benzoate, UV stabilizer, butylated hydroxy toluene, (DeTrey, Dentsply, Germany)] composite resin specimens, used in this study this three groups ( $\mathrm{n}=5$ discs, shade A1).

Fifteen disc specimens fabricated by using cylindrical Teflon mold 'each specimen was prepared as one increment and light cure to polymerized the resin composite from each side for $40 \mathrm{sec}$ using a light unit with intensity of power density of $355 \mathrm{~mW} / \mathrm{cm}^{2}$ (GNATUS, Fotopolimerizador optilight plus, Brasil). The specimens were polished with Sof-Lex system; 3M ESPE; specimens were stored in distilled water at $37^{\circ} \mathrm{C}$ for one week and then subjected to stain using iodine solution at $37^{\circ} \mathrm{C}$ for one week. All composite resin groups' discs specimens were placed (Beautifil II, IPS Empress Direct and Ceram.x.mono) in distilled water for one week to complete their polymerization. Then to stain, the composite resin groups specimens discs, immersion them in the iodine mouth wash solution (prepared by $5 \mathrm{~mL}$ povidone-iodine USP $1 \% \mathrm{w} / \mathrm{v}$, in $5 \mathrm{~mL}$ of distilled water according to the instruction of mouth wash use).

The absorbance of the specimen was measured at $355 \mathrm{~nm}$, using Cary 100 Bio UV-visible spectrophotometer Shimadzu and color changes were measured using a Vita Easy Shade device and put disc on black paper (VITAZahnfabrik H. Rauter Gmbh \& Co. KG, Bad Säckingen, Germany), they calibrated, according to timetable as shown in Table-1.

The colorimeter display the different color parameters $\mathrm{L}^{*}$, $a^{*}$ and $b^{*}$ according to the CIE L*, $\mathrm{a}^{*}, \mathrm{~b}^{*}$ space system, where $\mathrm{L}^{*}$ describes the luminance reflectance, while $\mathrm{a}^{*}$ and $\mathrm{b}^{*}$ describe the red-green and yellow-blue color coordinates, respectively.

The test measures $\mathrm{L}^{*}, \mathrm{a}^{*}$, and $\mathrm{b}^{*}$ space system and this system are referred to as CIEL*a*b*. In the color space, $\mathrm{L}^{*}$ indicates lightness $(\mathrm{L}+=$ lightness and $\mathrm{L}-=$ darkness $)$, the $\mathrm{a}^{*}$ coordinate represents the red/green range $\left(\mathrm{a}^{*}+=\right.$ redness and

TABLE-1

TIMETABLE AND PATHWAY DISTRIBUTION OF GROUPS' SPECIMENS

\begin{tabular}{c|c|c}
\hline $\begin{array}{c}\text { Beautifil II groups specimens } \\
\text { before stain }\left(\mathrm{B}_{1}\right) \\
\text { G1a }\end{array}$ & $\begin{array}{c}\text { IPS Empress Direct groups } \\
\text { specimens' before stain }\left(\mathrm{E}_{1}\right) \\
\text { G2a }\end{array}$ & $\begin{array}{c}\text { Ceram.x.mono groups specimens } \\
\text { before stain }\left(\mathrm{C}_{1}\right) \\
\text { G3a }\end{array}$ \\
\hline & & \\
\hline $\begin{array}{c}\text { Beautifil II groups specimens } \\
\text { after stain }\left(\mathrm{B}_{2}\right)\end{array}$ & $\begin{array}{c}\text { IPS Empress Direct groups } \\
\text { specimens after stain }\left(\mathrm{E}_{2}\right)\end{array}$ & $\begin{array}{c}\text { Ceram.x.mono groups specimens } \\
\text { after stain }\left(\mathrm{C}_{2}\right) \\
\text { G3b }\end{array}$ \\
\hline G1b & G3b & $\begin{array}{c}\text { Ceram.x.mono groups specimens } \\
\text { after bleach }\left(\mathrm{C}_{3}\right) \\
\text { G3c }\end{array}$ \\
\hline
\end{tabular}




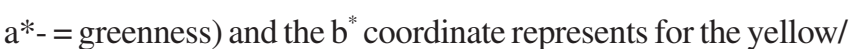
blue range $\left(b^{*}+=\right.$ yellowness and $b^{*}-=$ blueness $)$.

The values of the coordinates $a^{*}$ and $b^{*}$ approach zero, indicating neutral color (white and grey) and an increase in magnitude for more saturated or intense color ${ }^{33}$. The CIE L*, $a^{*}, b^{*}$ space system allows the numeric definition of a color as well as the difference between two color using the following formula:

$$
\Delta \mathrm{E}=\left[\left(\mathrm{L}_{1}-\mathrm{L}_{0}\right)^{2}+\left(\mathrm{a}_{1}-\mathrm{a}_{0}\right)^{2}+\left(\mathrm{b}_{1}-\mathrm{b}\right)^{2}\right]^{1 / 2}
$$

The change in color from baseline was calculated $\left(\Delta \mathrm{E}_{1}\right)$, after staining $\left(\Delta \mathrm{E}_{2}\right)$ and after the aqueous suspensions of titanium dioxide $\left(\mathrm{TiO}_{2}\right)$ session $\left(\Delta \mathrm{E}_{3}\right)$. The change in color after staining and the bleaching compared to the color after staining was also calculated. $\Delta \mathrm{E}$ values obtained using the Hunter's equation (Central Bureau of the International Commission on Illumination Colorimetric CIE publication. Vienna, Austria: 1986).

$$
\Delta \mathrm{E}=\left[(\Delta \mathrm{L})^{2}+(\Delta \mathrm{a})^{2}+(\Delta \mathrm{b})^{2}\right]^{1 / 2}
$$

Data were statistically analyzed using SPSS 20 package (Chicago, Illinois, U.S.A.). Regression models with one-way ANOVA and Tukey's post-hoc tests used to test significance of the effects of composite material and bleaching agent on color at $\mathrm{P} \leq 0.05$.

Photocatalytic reactor is shown in Fig. 1.

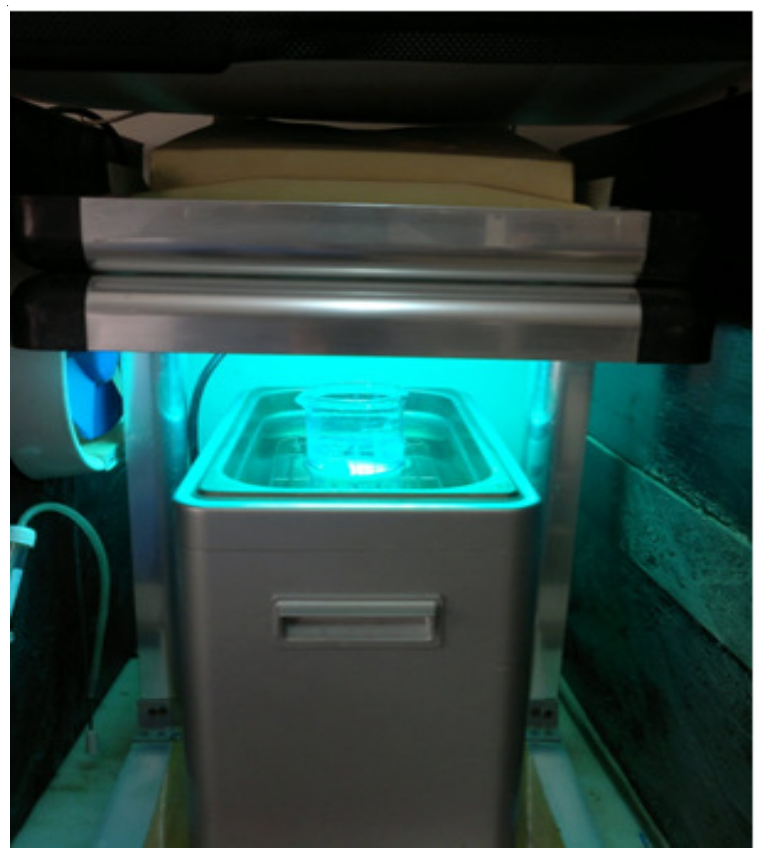

Fig. 1. Photocatalytic reactor
The photocatalytic reactions carried out in a batch photoreactor with the radiation source type Philips (CLEO), Poland, mercury lamps containing 6 lamps with $15 \mathrm{~W}$ for each. Aqueous suspensions of titanium dioxide $\left(\mathrm{TiO}_{2}\right)$ containing specimens in beaker, under sonication, were irradiated in light of wavelength $365 \mathrm{~nm}$ with an irradiation intensity of $3 \mathrm{~mW} \mathrm{~cm}^{-2}$. In all experiments, the required amount of the catalyst was suspended in $100 \mathrm{~cm}^{3}$ of aqueous solution of specimens. After illumination, $2 \mathrm{~mL}$ was taken from the reaction suspension, centrifuged at 4,000 rpm for $15 \mathrm{~min}$ in an $800 \mathrm{~B}$ centrifuge, the absorbance of the specimens was measured at $355 \mathrm{~nm}$, using Cary 100Bio UV-visible spectrophotometer Shimadzu.

\section{RESULTS AND DISCUSSION}

The color changes evaluation can performed either by using a colorimeter or, by visual assessment and spectrophotometry as were used in dentistry, which expresses color coordinates according to the CIE $\mathrm{L}^{*}, \mathrm{a}^{*}, \mathrm{~b}^{*}$ space system. These methods generally considered more precise, as they eliminate subjective errors ${ }^{32}$.

The $\Delta \mathrm{E}$ value is expressed as a relative color change between successive color measurements, the $\Delta \mathrm{E}=3.3$ value considered clinically perceptible according to the CIELab color space. The color space more popular and developmental for characterization of color based on human perception ${ }^{30,33,34}$.

Tables 2-4 represent the statistical mean and standard deviation, comparison of color changes testing $(\Delta \mathrm{E})$ when compared with groups' specimens at different time interval before iodine staining. After iodine staining and after aqueous suspensions of titanium dioxide $\left(\mathrm{TiO}_{2}\right)$ treatment, for Beautifill II, IPS Empress Direct and Ceram.x.mono composite resin group's specimens respectively. As for composite resin group's specimens: total color change $(\Delta \mathrm{E})$ after staining treatment when compared to before staining, also the total color change $(\Delta \mathrm{E})$ after aqueous suspensions of titanium dioxide $\left(\mathrm{TiO}_{2}\right)$ treatment when compared to after staining for all composite resin group's specimens.

Result of Beautiful composite resin group (G1a) showed there were significant effect $(\mathrm{p}=0.00)$ when compere $\Delta \mathrm{E}$, color changes after stain $(\Delta \mathrm{E}=0.08)$ with $\Delta \mathrm{E}$, color changes after aqueous suspensions of titanium dioxide $\left(\mathrm{TiO}_{2}\right)$ treatment $(\Delta \mathrm{E}=12.14)$.

Result of Table-3 for group three for IPS Empress Direct composite resin (G2) showed there were significant effect ( $p$ $=0.00$ ) when compere $\Delta \mathrm{E}$ color changes of IPS Empress Direct

\begin{tabular}{|c|c|c|c|c|c|c|}
\hline \multirow[b]{2}{*}{ Group one (G1) } & \multirow[b]{2}{*}{ Range } & \multirow{2}{*}{$\begin{array}{c}\text { Mean } \\
(\Delta \mathrm{E}, \text { color } \\
\text { changes })\end{array}$} & \multirow{2}{*}{$\begin{array}{c}\mathrm{SD} \\
(\Delta \mathrm{E}, \text { color } \\
\text { changes })\end{array}$} & \multicolumn{3}{|c|}{ Difference between groups } \\
\hline & & & & $\begin{array}{l}\text { Groups } \\
\text { Compared }\end{array}$ & $\begin{array}{c}\text { Mean } \\
\text { difference }\end{array}$ & ${ }^{\text {a.P-Value }}$ \\
\hline $\begin{array}{l}\text { ( } \Delta \mathrm{E}, \text { color changes) Beautifill-II composite } \\
\text { resin before stain (G1a) }\end{array}$ & $0.0-0.1$ & 0.08 & 0.04 & (G1a)-(G1b) & $-21.53^{*}$ & $0.00 *$ \\
\hline $\begin{array}{l}\text { ( } \Delta \mathrm{E}, \text { color changes) Beautifill-II composite } \\
\text { resin after stain (G1b) }\end{array}$ & $21.61-21.62$ & 21.61 & 0.00 & $(\mathrm{G} 1 \mathrm{~b})-(\mathrm{G} 1 \mathrm{c})$ & $9.47 *$ & $0.00 *$ \\
\hline $\begin{array}{l}\text { ( } \Delta \mathrm{E} \text {, color changes) Beautifill-II composite } \\
\text { resin after aqueous suspensions of titanium } \\
\text { dioxide treatment }(\mathrm{G} 1 \mathrm{c})\end{array}$ & $21.13-21.15$ & 12.14 & 0.00 & (G1c)- (G1a) & $12.06 *$ & $0.00 *$ \\
\hline
\end{tabular}

TABLE-2 
composite resin after stain $(\Delta \mathrm{E}=0.12)$ with $\Delta \mathrm{E}$ color changes IPS Empress Direct composite resin after aqueous suspensions of titanium dioxide $\left(\mathrm{TiO}_{2}\right)$ treatment $(\Delta \mathrm{E}=32.97)$.

Result of Table-4 of the Ceram.x.mono composite resin group (G3) showed there were significant effect $(\mathrm{p}=0.00)$ when compere $\Delta \mathrm{E}$ color changes after stain $(\Delta \mathrm{E}=0.22)$ with $\Delta \mathrm{E}$ color changes of the after the aqueous suspensions of titanium dioxide $\left(\mathrm{TiO}_{2}\right)$ treatment $(\Delta \mathrm{E}=16.04)$.

In study by Suyama et $a l^{30}$, the effects of various light sources on the bleaching action by using titanium dioxide
$\left(\mathrm{TiO}_{2}\right)$ photocatalysts in an ultraviolet light-activated photo catalyst $\left(\mathrm{UVTiO}_{2}\right)$, versus a visible light-activated photo catalyst $\left(\mathrm{VL}-\mathrm{TiO}_{2}\right)$. They showed high-intensity halogen with VL-TiO ${ }_{2}+\mathrm{H}_{2} \mathrm{O}_{2}$ caused the most significant reduction in methylene blue concentration, and the effect of light sources, the halogen lamps resulted in a greater bleaching effect than the blue $\mathrm{LED}^{30}$.

Tables 4-6 showed the color changes $(\Delta \mathrm{E})$ represented as bleaching effect on specimens by the effect of aqueous suspensions of titanium dioxide $\left(\mathrm{TiO}_{2}\right)$ treatment, as in-group IPS

\begin{tabular}{|c|c|c|c|c|c|c|}
\hline \multicolumn{7}{|c|}{$\begin{array}{l}\text { TABLE-3 } \\
\text { MEANS AND STANDARD DEVIATION VALUES FOR COLOR CHANGE }(\Delta \mathrm{E}) \\
\text { FOR THE IPS EMPRESS DIRECT GROUPS }(\mathrm{G} 2) \text { IN SHADE A1 }(\mathrm{n}=5)\end{array}$} \\
\hline \multirow[b]{2}{*}{ Group (G2) } & \multirow[b]{2}{*}{ Range } & \multirow{2}{*}{$\begin{array}{c}\text { Mean } \\
(\Delta \mathrm{E}, \text { color } \\
\text { changes })\end{array}$} & \multirow{2}{*}{$\begin{array}{c}\mathrm{SD} \\
(\Delta \mathrm{E}, \text { color } \\
\text { changes })\end{array}$} & \multicolumn{3}{|c|}{ Difference between groups } \\
\hline & & & & $\begin{array}{l}\text { Groups } \\
\text { Compared }\end{array}$ & $\begin{array}{c}\text { Mean } \\
\text { difference }\end{array}$ & a.P-Value \\
\hline $\begin{array}{l}(\Delta \mathrm{E}, \text { color changes }) \\
\text { IPS Empress Direct composite } \\
\text { resin before stain }(\mathrm{G} 2 \mathrm{a})\end{array}$ & $0.1-0.2$ & 0.12 & 0.04 & $(G 2 a)-(G 2 b)$ & $-41.72 *$ & $0.00^{*}$ \\
\hline $\begin{array}{l}(\Delta \mathrm{E}, \text { color changes) IPS Empress Direct } \\
\text { composite resin after stain }(\mathrm{G} 2 \mathrm{~b})\end{array}$ & $41.77-42.02$ & 41.84 & 0.09 & $(\mathrm{G} 2 \mathrm{~b})-(\mathrm{G} 2 \mathrm{c})$ & $8.87 *$ & $0.00^{*}$ \\
\hline $\begin{array}{l}(\Delta \mathrm{E} \text {, color changes) IPS Empress Direct } \\
\text { composite resin after aqueous suspensions } \\
\text { of titanium dioxide treatment }(\mathrm{G} 2 \mathrm{c})\end{array}$ & $32.9-33.11$ & 32.97 & 0.09 & $(\mathrm{G} 2 \mathrm{c})-(\mathrm{G} 2 \mathrm{a})$ & $32.85^{*}$ & $0.00 *$ \\
\hline
\end{tabular}

\begin{tabular}{|c|c|c|c|c|c|c|}
\hline \multicolumn{7}{|c|}{$\begin{array}{c}\text { TABLE-4 } \\
\text { MEANS AND STANDARD DEVIATION VALUES FOR COLOR CHANGE }(\Delta \mathrm{E}) \\
\text { FOR THE CERAM.X.MONO GROUPS }(\mathrm{G} 3) \text { IN SHADE A1 }(\mathrm{n}=5)\end{array}$} \\
\hline \multirow[b]{2}{*}{ Group (G3) } & \multirow[b]{2}{*}{ Range } & \multirow{2}{*}{$\begin{array}{c}\text { Mean } \\
\text { ( } \Delta \mathrm{E}, \text { color } \\
\text { changes })\end{array}$} & \multirow{2}{*}{$\begin{array}{c}\mathrm{SD} \\
(\Delta \mathrm{E}, \text { color } \\
\text { changes })\end{array}$} & \multicolumn{3}{|c|}{ Difference between groups } \\
\hline & & & & $\begin{array}{l}\text { Groups } \\
\text { Compared }\end{array}$ & $\begin{array}{l}\text { Mean } \\
\text { difference }\end{array}$ & ${ }^{\mathrm{a}} \mathrm{P}$-Value \\
\hline $\begin{array}{l}(\Delta \mathrm{E}, \text { color changes) } \\
\text { Ceram.x.mono composite } \\
\text { resin before stain }(\mathrm{G} 3 \mathrm{a})\end{array}$ & $0.0-0.4$ & 0.22 & 0.13 & (G3)- (G3) & $-31.73^{*}$ & $0.00 *$ \\
\hline $\begin{array}{l}\text { ( } \Delta \mathrm{E}, \text { color changes) Ceram.x.mono } \\
\text { composite resin after stain (G3b) }\end{array}$ & $30.66-32.34$ & 31.95 & 0.68 & $(\mathrm{G} 3 \mathrm{~b}) .-(\mathrm{G} 3 \mathrm{c})$ & $15.9 *$ & $0.00^{*}$ \\
\hline $\begin{array}{l}\text { ( } \Delta \mathrm{E}, \text { color changes) Ceram.x.mono } \\
\text { composite resin aqueous suspensions of } \\
\text { titanium dioxide treatment }(\mathrm{G} 3 \mathrm{c})\end{array}$ & $16.02-16.05$ & 16.04 & 0.01 & $(\mathrm{G} 3 \mathrm{c})-(\mathrm{G} 3 \mathrm{a})$ & $15.82^{*}$ & $0.00^{*}$ \\
\hline
\end{tabular}

TABLE-5

MEANS AND STANDARD DEVIATION VALUES FOR 3D COLOR SPACE FOR THE THREE COMPOSITES GROUPS IN SHADE A1

\begin{tabular}{|c|c|c|c|}
\hline Time interval & $\begin{array}{c}\text { G1 } \\
\text { Mean, SD }\end{array}$ & $\begin{array}{c}\text { G2 } \\
\text { Mean, SD }\end{array}$ & $\begin{array}{c}\text { G3 } \\
\text { Mean, SD }\end{array}$ \\
\hline $\mathrm{L}^{*}$. Before staining treatment measure & $\begin{array}{c}76.08^{\mathrm{aA}} \\
0.04\end{array}$ & $\begin{array}{c}24.98^{\mathrm{dA}} \\
18.25\end{array}$ & $\begin{array}{c}57.90^{\mathrm{gA}} \\
2.79\end{array}$ \\
\hline $\mathrm{L}^{*}$. After staining treatment measure & $\begin{array}{c}76.12^{\mathrm{aB}} \\
0.04\end{array}$ & $\begin{array}{c}77.74^{\mathrm{dB}} \\
1.24\end{array}$ & $\begin{array}{c}64.20^{\mathrm{gB}} \\
0.00\end{array}$ \\
\hline $\mathrm{L}^{*}$. After aqueous suspensions of titanium dioxide $\left(\mathrm{TiO}_{2}\right)$ treatment measure & $\begin{array}{c}78.10^{\mathrm{aC}} \\
0.00\end{array}$ & $\begin{array}{c}76.30^{\mathrm{dC}} \\
0.00\end{array}$ & $\begin{array}{c}68.38^{\mathrm{gC}} \\
0.04\end{array}$ \\
\hline $\mathrm{a}^{*}$. Before staining treatment measure & $\begin{array}{c}1.50^{\mathrm{bD}} \\
0.00\end{array}$ & $\begin{array}{c}77.94^{\mathrm{eD}} \\
1.61\end{array}$ & $\begin{array}{c}-1.62^{\mathrm{hD}} \\
0.59\end{array}$ \\
\hline$a^{*}$. After staining treatment measure & $\begin{array}{c}2.40^{\mathrm{bE}} \\
0.00\end{array}$ & $\begin{array}{c}0.88^{\mathrm{eE}} \\
.042\end{array}$ & $\begin{array}{c}2.50^{\mathrm{hE}} \\
0.00\end{array}$ \\
\hline$a^{*}$. After aqueous suspensions of titanium dioxide $\left(\mathrm{TiO}_{2}\right)$ treatment measure & $\begin{array}{c}0.30^{\mathrm{bF}} \\
0.00\end{array}$ & $\begin{array}{c}0.10^{\mathrm{eF}} \\
0.00\end{array}$ & $\begin{array}{c}-2.68^{\mathrm{hF}} \\
0.04\end{array}$ \\
\hline$b^{*}$. Before staining treatment measure & $\begin{array}{c}15.40^{\mathrm{cG}} \\
0.00\end{array}$ & $\begin{array}{c}-0.11^{\mathrm{fG}} \\
0.91\end{array}$ & $\begin{array}{c}11.76^{\mathrm{kG}} \\
0.24\end{array}$ \\
\hline $\mathrm{b}^{*}$. After staining treatment measure & $\begin{array}{c}37.0^{\mathrm{cH}} \\
0.00\end{array}$ & $\begin{array}{c}7.88^{\mathrm{fH}} \\
0.17\end{array}$ & $\begin{array}{c}42.70^{\mathrm{kH}} \\
0.00\end{array}$ \\
\hline $\mathrm{b}^{*}$. After aqueous suspensions of titanium dioxide $\left(\mathrm{TiO}_{2}\right)$ treatment measure & $\begin{array}{c}25.20^{\mathrm{cI}} \\
0.00\end{array}$ & $\begin{array}{c}49.68^{\mathrm{fI}} \\
0.13\end{array}$ & $\begin{array}{c}28.10^{\mathrm{kI}} \\
0.00\end{array}$ \\
\hline
\end{tabular}




\begin{tabular}{|c|c|c|c|c|c|c|}
\hline \multicolumn{7}{|c|}{$\begin{array}{l}\text { TABLE-6 } \\
\text { ANOVA TEST FOR ALL THREE COMPOSITE RESINS GROUPS OF THE SPECIMENS' } \\
\text { MEASUREMENT FOR } \triangle \text { E COLOR CHANGES AND 3D COLOR SPACE }\end{array}$} \\
\hline \multicolumn{7}{|c|}{ ANOVA } \\
\hline & & Sum of squares & $\mathrm{df}$ & Mean square & $\mathrm{F}$ & P-value \\
\hline \multirow{3}{*}{$\Delta \mathrm{E}$-Color change } & Between groups & 2899.635 & 2 & 1449.818 & 7.405 & $0.001 *$ \\
\hline & Within groups & 17034.789 & 87 & 195.802 & & \\
\hline & Total & 19934.424 & 89 & & & \\
\hline \multirow{3}{*}{$\mathrm{L}^{*}$} & Between groups & 3862.643 & 2 & 1931.321 & 230.538 & $0.000^{*}$ \\
\hline & Within groups & 728.837 & 87 & 8.377 & & \\
\hline & Total & 4591.480 & 89 & & & \\
\hline \multirow{3}{*}{$a^{*}$} & Between groups & 65.134 & 2 & 32.567 & 14.199 & $0.000^{*}$ \\
\hline & Within groups & 199.539 & 87 & 2.294 & & \\
\hline & Total & 264.673 & 89 & & & \\
\hline \multirow{3}{*}{$\mathrm{b}^{*}$} & Between groups & 110.692 & 2 & 55.346 & .287 & 0.752 \\
\hline & Within groups & 16805.733 & 87 & 193.169 & & \\
\hline & Total & 16916.425 & 89 & & & \\
\hline
\end{tabular}

Empress Direct composite resin after stain $(\mathrm{G} 2 \mathrm{c})$, then group Ceram.x.mono composite resin after stain $(\mathrm{G} 3 \mathrm{c})$.

Table- 5 showed the aqueous suspensions of titanium dioxide $\left(\mathrm{TiO}_{2}\right)$ treatment effect in 3D space is the $\mathrm{L} *$ (mean $=$ 68.38 which mean get more dark area in color) of the group Ceram.x.mono composite resin (G3c) after treatment by aqueous suspensions of titanium dioxide $\left(\mathrm{TiO}_{2}\right)$.

Table-6 showed the data submitted to two-way ANOVA $(\mathrm{p}<0.00)$ and post hoc tests. Statistical difference observed between all groups. It has had been concluded that G2c (E3), showed significantly higher effect of the aqueous suspensions of titanium dioxide $\left(\mathrm{TiO}_{2}\right)$ treatment changes than the G1c (B3) group.

$(\mathrm{G} 2 \mathrm{~b})$ and $(\mathrm{G} 3 \mathrm{~b})$ (mean $=0.88$ and 2.50$)$ respectively, showed intermediary pigmentation more than $(\mathrm{G} 1 \mathrm{~b})$ group and in ANOVA test showed not significant of $b^{*}$.

The more significant effect (mean=-2.68) in 3D space is the $\mathrm{a}^{*}$ of the G3c Ceram.x.mono after aqueous suspensions of titanium dioxide $\left(\mathrm{TiO}_{2}\right)$ treatment (Table-5).

Tables 7-9 showed there were all groups' increase of the absorbance with the increasing time exposer increase and increase in the group 1 and group 2 more than group 3 .
TABLE-7

ABSORBANCE DEGREES IN ALL THREE COMPOSITE RESINS GROUPS' OF THE SPECIMENS' MEASUREMENT WITHIN ALL TIMES INTERVALS

\begin{tabular}{cccc}
\hline Group & Group1 & Group2 & Group3 \\
\hline $\mathrm{t}(\mathrm{min})$ & Beautifil II & $\begin{array}{c}\text { IPS Empress } \\
\text { Direct }\end{array}$ & Ceram.x.mono \\
\hline 0 & 0.101 & 0.097 & 0.085 \\
5 & 0.132 & 0.114 & 0.099 \\
10 & 0.144 & 0.161 & 0.135 \\
15 & 0.198 & 0.192 & 0.161 \\
30 & 0.213 & 0.218 & 0.183 \\
\hline
\end{tabular}

In all 'between groups' of $\Delta \mathrm{E}-$-Color change, $\mathrm{L}^{*}, \mathrm{a}^{*}, \mathrm{~b}^{*}$ respectively showed significant $\mathrm{p}$ values $=0.001,0.000$ and 0.000 , respectively, there were effect of the aqueous suspensions of titanium dioxide $\left(\mathrm{TiO}_{2}\right)$ treatment on the color changes composite groups specimens, except $b^{*}$ showed not significant effect $(p=0.752)$ in all composite groups specimens (Table$6)$.

Table-8 showed multiple comparisons of the absorbance in all groups, through different time intervals, among all groups only the time 5 min not significant difference $(\mathrm{p}=1.000)$, that showed there were no effect titanium dioxide at absorbance

\section{TABLE-8}

MULTIPLE COMPARISONS OF THE ABSORBANCE IN ALL GROUPS, THROUGH DIFFERENT TIME INTERVALS

\begin{tabular}{cccccc}
\hline & \multicolumn{2}{c}{ Bonferroni } & & \\
\hline Dependent Variable & (I) Absorbance time & (J) Absorbance time & Mean Difference (I-J) & Std. Error & P-value \\
\hline \multirow{3}{*}{ Absorbance } & \multirow{3}{*}{0 -time } & 5-time & -.02067 & 0.013 & 1.000 \\
& & 10 -time & $-.05233^{*}$ & 0.013 & $0.024^{*}$ \\
& & 15 -time & $-.08933^{*}$ & 0.013 & $0.000^{*}$ \\
\hline
\end{tabular}

"Mean difference is significant at the 0.05 level

TABLE-9

ANOVA TEST FOR ALL THREE COMPOSITE RESINS GROUPS' ABSORBANCE OF THE SPECIMEN'S MEASUREMENT AT ALL TIME

\begin{tabular}{ccccccc}
\hline & & Sum of Squares & df & Mean Square & F & P-value \\
\hline \multirow{3}{*}{ Absorbance } & Between roups & 0.025 & 4 & 0.006 & 24.965 & $0.000^{*}$ \\
& Within Groups & 0.003 & 10 & 0.000 & & \\
& Total & 0.028 & 14 & & & \\
\hline
\end{tabular}

Mean difference is significant at the 0.05 level 
of the specimens measurement at this groups in within this times intervals $(0,5 \mathrm{sec}$, respectively).

Table-9 showed all groups were significant difference ( $p=0.000$ ), that showed there were effect titanium dioxide on absorbance of the specimens' measurement at these groups.

\section{Conclusions}

- The photocatalytic reaction of aqueous suspensions of titanium dioxide had reduced $(\Delta \mathrm{E})$ color change values in all stained specimens of the three composite resins groups.

- The $(\Delta \mathrm{E})$ color change values in all the three composite resins groups' were responded not similarly to photocatalytic reaction of aqueous suspensions of titanium dioxide $\left(\mathrm{TiO}_{2}\right)$.

- The absorbance degree in all the three composite resins groups' increase with the increasing of exposer time of the photocatalytic reaction.

\section{REFERENCES}

1. G. Kugel and S. Kastali, Compend. Contin. Educ. Dent., 29, 516(2000).

2. J.E. Dahl and U. Pallesen, Crit. Rev. Oral Biol. Med., 14, 292 (2003).

3. T. Attin, C. Hannig, A. Wiegand and R. Attin, Dent. Mater., 20, 852 (2004).

4. S. Canay and M. Cehreli, J. Prosthet. Dent., 89, 474 (2003).

5. P. Villalta, H. Lu, Z. Okte, F. Garcia-Godoy and J. Powers, J. Prosthet. Dent., 95, 137 (2006).

6. J.H. Kim, Y.K. Lee, B.S. Lim, S.H. Rhee and H.C. Yang, Clin. Oral Investig., 8, 118 (2004).

7. P. Monaghan, E. Lim and E. Lautenschlager, J. Prosthet. Dent., 68, 575 (1992).

8. F. Yalcin and S. Gurgan, J. Biomater. Appl., 19, 187 (2005).

9. F. Yalcin and S. Gurgan, Dent. Mater., 21, 464 (2005).

10. R.M. Fay, T. Servos and J.M. Powers, Oper. Dent., 24, 292 (1999).

11. S.B. Turker and T. Biskin, J. Prosthet. Dent., 89, 466 (2003).
12. E. Assmussen, Scand. J. Dent. Res., 92, 257 (1984).

13. E. Assmussen, Scand. J. Dent. Res., 90, 490 (1982).

14. W. Wu and J.E. McKinney, J. Dent. Res., 61, 1180 (1982).

15. N. Abu-Bakr, L. Han, A. Okamoto and M. Iwaku, J. Esthet. Dent., 12, 258 (2000)

16. B.A. Matis, M. Youset, M.A. Cochram and G.J. Eckert, Oper. Dent., 27, 12 (2002)

17. V.B. Haywood and H.O. Heymann, Quint. Int., 20, 173 (1989).

18. L. Greenwall, Bleaching Techniques in Restorative Dentistry, An illustrated Guide, Martin Duntz Ltd; United Kingdom (2001).

19. K.A. Schulze, S.J. Marshall, S.A. Gansky and G.W. Marshall, Dent. Mater., 19, 612 (2003).

20. R. Janda, J.F. Roulet, M. Kaminsky, G. Steffin and M. Latta, Eur. J. Oral Sci., 112, 280 (2004).

21. E. Ertas, A.U. Güler, A.Ç. Yücel, H. Köprülü and E. Güler, Dent. Mater. J., 25, 371 (2006).

22. R. Bagheri, M.F. Burrow and M. Tyas, J. Dent., 33, 389 (2005).

23. M. Fujita, S. Kawakami, M. Noda and H. Sano, Dent. Mater. J., 25, 352 (2006).

24. H. Lu, L.B. Roeder, L. Lei and J.M. Powers, J. Esthet. Restor. Dent., 17, 102 (2005)

25. O. Polydorou, E. Hellwig and T.M. Auschill, Oper. Dent., 31, 473 (2006).

26. V. Mathai, M.C. Angelo, K. Mariamma, K. Jayakumar and K.S. Babu, Int. J. Anal. Pharm. Biomed. Sci., 2, 18 (2013).

27. M.B. D'Arce, D.A. Lima, F.H. Baggio Aguiar, C.E. Bertoldo, G.M. Ambrosano and J.R. Lovadino, J. Clin. Exp. Dent., 5, 100 (2013).

28. A. Fujishima and K. Honda, Nature, 238, 37 (1972).

29. T. Suemori, J. Kato, T. Nakazawa, G. Akashi, A. Igarashi, Y. Hirai, Y. Kumagai and H. Kurata, Laser Phys., 5, 379 (2008).

30. Y. Suyama, M. Otsuki, S. Ogisu, R. Kishikawa, J. Tagami, M. Ikeda, H. Kurata and T. Cho, Dent. Mater. J., 28, 693 (2009).

31. A. Joiner, J. Dent., 32, 3 (2004).

32. W.M. Johnston and E.C. Kao, J. Dent. Res., 68, 819 (1989).

33. I.E. Ruyter, K. Nilner and B. Möller, Dent. Mater., 3, 246 (1987).

34. R.R. Seghi, E.R. Hewlett and J. Kim, J. Dent. Res., 68, 1760 (1989). 